\title{
SCREENING THE TOXICITY AND TOXIN CONTENT OF BLOOMS OF THE CYANOBACTERIUM Trichodesmium erythraeum (EHRENBERG) IN NORTHEAST BRAZIL
}

\section{Proença LAO (1), Tamanaha MS (1), Fonseca RS (1)}

(1) Center of Technological Earth and Marine Sciences, Vale do Itajaí University, Itajaí, Santa Catarina State, Brazil.

\begin{abstract}
Blooms of the cyanobacterium Trichodesmium occur in massive colored patches over large areas of tropical and subtropical oceans. Recently, the interest in such events has increased given their role in major nitrogen and carbon dioxide oceanic fluxes. Trichodesmium occurs all along the Brazilian coast and patches frequently migrate towards the coast. In this paper we screen the toxicity and toxin content of Trichodesmium blooms off the coast of Bahia state. Four samples, collected from February to April 2007, were analyzed. Organisms were identified and assessed for toxicity by means of several methods. Analogues of microcystins, cylindrospermopsins and saxitoxins were analyzed using HPLC. Microcystins were also assayed through ELISA. Results showed dominance of $T$. erythraeum, which makes up as much as $99 \%$ of cell counts. Other organisms found in smaller quantities include the dinoflagellates Prorocentrum minimum and $P$. rhathymum. Extracts from all samples delayed or interrupted sea urchin larval development, but presented no acute toxicity during a mouse bioassay. Saxitoxin congeners and microcystins were present at low concentrations in all samples, occurrences that had not previously been reported in the literature. Despite our finding of saxitoxin analogues and microcystins in Trichodesmium blooms, these toxins do not represent a potential harm to human health by primary contact. We conclude, based on our results and those reported in the recent literature, which differ from results published in 1963, that although toxins are present, there is no evidence that $T$. erythraeum blooms represent a threat to humans.
\end{abstract}

KEY WORDS: saxitoxin, microcystin, harmful algae, Trichodesmium, bloom.

CONFLICTS OF INTEREST: There is no conflict.

\section{CORRESPONDENCE TO:}

LUÍS ANTÔNIO DE OLIVEIRA PROENÇA, Centro de Ciências Tecnológicas da Terra e do Mar, Universidade do Vale do Itajaí, Rua Uruguai, 458, Itajaí, SC, 88303202, Brasil. Phone: + 5547341 7541. Email: luis.proenca@univali.br. 
Proença LAO et al. Screening the toxicity and toxin content of blooms of the cyanobacterium Trichodesmium erythraeum (Ehrenberg) in northeast Brazil. J Venom Anim Toxins incl Trop Dis. 2009;15(2):205

\section{INTRODUCTION}

The genus of the cyanobacterium Trichodesmium ( $T$. erithraeum Ehrenberg ex Gomont) was first found by Ehrenberg (1830) in the Red Sea. Since then, several species - including T. erythraeum Ehrenberg, T. thiebautii Gomont ex Gomont, T. contortum (Wille) Wille, T. radians (Wille) Golubić and T. hildebrantii Gomont - have been identified (1). Trichodesmium form blooms that can occur in a large area covering the tropical and subtropical regions of the Atlantic, Pacific and Indian oceans as well as the China and Caribbean Seas. The genus is generally characterized by cylindrical trichomes and forms colonies with varied morphology (2). Lately, the interest in Trichodesmium blooms has increased due to their biological and ecological characteristics that include fixation of atmospheric nitrogen and carbon dioxide (3). Diazotrophic cells do not show differentiated structures like other cyanobacteria and, as they usually occur in oligotrophic waters, their impact on global fluxes of nitrogen and carbon as well as on organic matter production are of great interest.

Usually, species of Trichodesmium are found in the most stable surface layers, and within the mixed layer down to 100 meters depth. During the blooms, conspicuous extensive patches can be seen even from space by satellites (3). This pattern is possibly due to the presence of gas vacuoles that provide positive flotation and accessory pigments, permitting Trichodesmium to resist high levels of radiation exposure. The colors of the patches change according to the cell's physiological state, and can be greenish, brownish, whitish, yellowish or reddish $(4,5)$. The structure of the plankton community is affected by Trichodesmium due to the production of toxins that can act allopathically against grazers (6).

Trichodesmium is found along most of the Brazilian coast and is associated with the Brazilian Current. It occurs along the coast of Rio Grande do Sul, Santa Catarina (4), Paraná $(7,8)$ and São Paulo (9-11). The study by Satô, Paranaguá and Eskinazi (5) is one of the most frequently cited papers on this topic and reports blooms off the coastal area of Recife, in northeastern Brazil. The authors associate the illness of beach users, known as Tamandaré's fever or "tinguí", with the occurrence of $T$. erythraeum blooms (5). Along the coast of Santa Catarina state, Trichodesmium blooms are generally found from November through April and are associated with calm periods and low nitrogen-to-phosphorous ratios $(7,4)$. The patches can be as large as $100 \mathrm{~km}$ in length, as reported in February of 2000 when they were located 
about $80 \mathrm{~km}$ off the coast of São Paulo (8). Despite their widespread occurrence, no other publications have connected $T$. erythraeum blooms to human illness, except for the study published by Satô, Paranaguá and Eskinazi (5). However, it is currently reported as a potentially harmful species.

This paper aims to investigate the occurrence of Trichodesmium blooms in Camamu bay in the coast of Bahia, northeast Brazil, and to characterize their toxicity and potential harmful effects.

\section{MATERIALS AND METHODS}

Four samples were collected from four different patches of Trichodesmium ssp. blooms near the coastal platform off Camamu-Almada, in the Boipeba Island and Maraú peninsula on the coast of Bahia state (Figure 1). The samples were collected

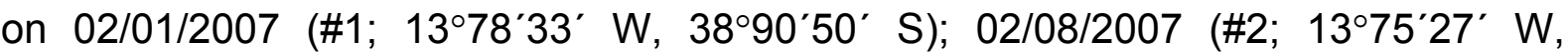

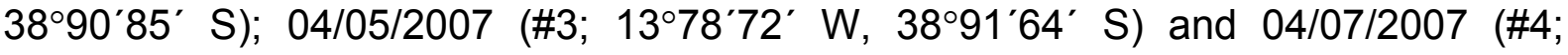
$\left.13^{\circ} 75^{\prime} 99^{\prime} \mathrm{W}, 38^{\circ} 86^{\prime} 50^{\prime} \mathrm{S}\right)$ and then fixed in a $2 \%$ formalin solution to permit the identification and counting of phytoplankton. The scum was concentrated on a piece of filter paper and frozen at $-18^{\circ} \mathrm{C}$ for toxin analysis and toxicity assays.

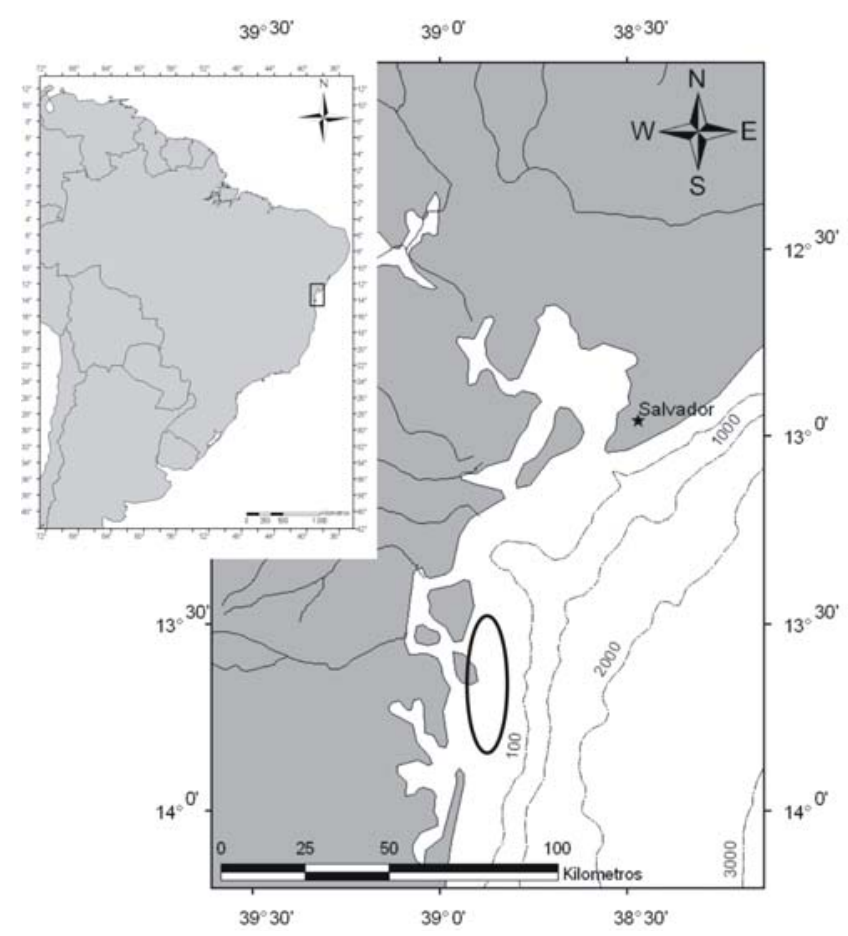

Figure 1. Camamu-Almada region off Bahia state, in northeastern Brazil, including areas of sample collections. 
Samples fixed in formalin were observed through a binocular microscope for species identification. Trichodesmium cell counts were calculated by determining the average number of cells per trichome (30 trichomes per sample) in a $1 \mathrm{~mL}$ Sedgwick-Rafter and expressing the final cell counts as cell/L. The other organisms were counted in an IX 50 inverted microscope (Olympus, Japan) using Utermhöll $3 \mathrm{~mL}$ settling chambers at respective magnifications of 200 and 400x (12). All organisms were identified to the most precise taxonomic level possible $(2,13-15)$.

The presence of phycotoxins was investigated by high performance liquid chromatography (HPLC) and bioassays. Each sample was initially weighed (wet weight) and then dried at $40^{\circ} \mathrm{C}$ for 24 hours in an oven and subsequently reweighed (dry weight). The dried samples were extracted into 3 to $5 \mathrm{~mL}$ volumes of $80 \%$ methanol. A $500 \mu \mathrm{L}$ subsample was saved for HPLC analysis as described subsequently. Before the assays, the extracts were clarified in fiberglass filters and dried in a rotoevaporator to eliminate the methanol. Again, a subsample was preserved for the sea urchin test and the remainder partitioned with ethyl acetate. The two phases were dried and assayed by means of a mouse bioassay.

For the sea urchin larval assay, to test its activity, $10 \mathrm{~mL}$ of the extract was put into $15-\mathrm{mL}$ flasks, after correcting the salinity to $30 \%$. In each flask, $200 \mu \mathrm{L}$ of fertilized egg suspension, containing a minimum of 300 eggs, was added. Eggs and sperm of Lytechinus variegatus Lamarck had been obtained by previous spawning induction with injections of $\mathrm{KCl} 0.1 \mathrm{M}$. The test was carried out for 24 hours at controlled temperature $\left(25^{\circ} \mathrm{C}\right)$ and illumination (12:12 light and dark cycle) (16). The test ended with the addition of formalin solution (4\%). Six dilutions of the initial extract from the dried material were tested $(100,50,25,12.5,6.1$ and $3.7 \%)$ and compared with the control containing marine water.

The mouse bioassays were based on Harada et al. (17) and consisted of the intraperitoneal inoculation of $1 \mathrm{~mL}$ of both hydrophilic and lipophilic phases of the extract. Three Swiss mice, weighing between 17 and 20 grams were used, and tested for 24 hours with water and food ad libidum. The extracts had been diluted to obtain a salinity of $0.9 \%$. The injected dose was based on the toxicity scale for cyanobacteria, as follows: more than $1,000 \mathrm{mg} / \mathrm{kg} \rightarrow$ non-toxic; 1,000 to $500 \mathrm{mg} / \mathrm{kg}$ $\rightarrow$ low toxicity; 500 to $100 \mathrm{mg} / \mathrm{kg} \rightarrow$ high toxicity (18). ELISA assays for microcystin were performed only on the sample collected on 04/07/2007 using a microcystin plate ELISA kit (Beacon Analytical Systems Inc., USA). 
HPLC analysis of saxitoxin and congeners, microcystins and cylindrospermopsin were carried out on the initial $80 \%$ methanolic extract using a HPLC system (Shimadzu, Japan) as described below. Saxitoxin and congeners were analyzed according to the post-column derivatization method (19). The chromatography was conducted at $30^{\circ} \mathrm{C}$ on a Luna ${ }^{\circ} 4.6 \times 250 \mathrm{~mm}$ column (Phenomenex, USA) filled with $5 \mu \mathrm{m}$ C8 particles. After the chromatography, the column eluents were derivatized with buffered $50 \mathrm{nM}$ periodic acid and stabilized with acetic acid using a two-piston LC $10 \AA$ pump (Shimadzu, Japan). The peaks were detected on a RF 10Alx® fluorometer (Shimadzu, Japan). Two runs with different mobile phases were performed for each sample to separately determine gonyautoxins (GTX1-GTX4), decarbamoyl gonyautoxins (dcGTX2, dcGTX3) and saxitoxin (STX), neosaxitoxin (neoSTX) and decarbomoyl neosaxitoxin (dcSTX). The system was calibrated with a standard purchased from the National Research Council, Canada.

HPLC analysis of cylindrospermopsin was carried out according to methods described by Li et al. (20), using a Lichrosphere RP 18® (Merck , Germany) (5 $\mu \mathrm{m})$ $(125 \times 4.6 \mathrm{~mm})$ column whereas detection was conducted by means of a diode array SPD M10A® (Shimadzu, Japan). The process was calibrated with pure cylindrospermopsin acquired from CyanoHAB, USA. The same column and equipment were employed to investigate microcystin. The system was calibrated with pure microcystin-LR (Sigma Chemical Co., USA). The four standards (Dleu-LR-Mic, LY, LW and LF) were kindly provided by Dr. Yunes from the Federal University of Rio Grande, FURG.

\section{RESULTS AND DISCUSSION}

The microscopic analysis in all samples confirmed that the blooming organism, forming the patches, was the cyanobacterium $T$. erythraeum, with cell counts as high as $577.20 \times 10^{6} \mathrm{cell} / \mathrm{L}$ (found in sample \#2 from 02/08/2007). The conspicuous brownish patches presented different shapes and sizes, ranging from a few meters to several kilometers. The lowest count, $8.32 \times 10^{6}$ cell/L, was found in sample \#4 from 04/07/2007. The solitary or colony-forming parallel straight $T$. erythraeum trichomes, with an attenuated end cell, presented cells measuring from 7.5 to $15 \mu \mathrm{m}$ in width and $5 \mu \mathrm{m}$ in height. The trichome length ranged from 246 to $417 \mu \mathrm{m}$ with a cell number ranging from 49 to 83 . The number of trichomes per colony varied from 29 to 44 (Figure 2). 


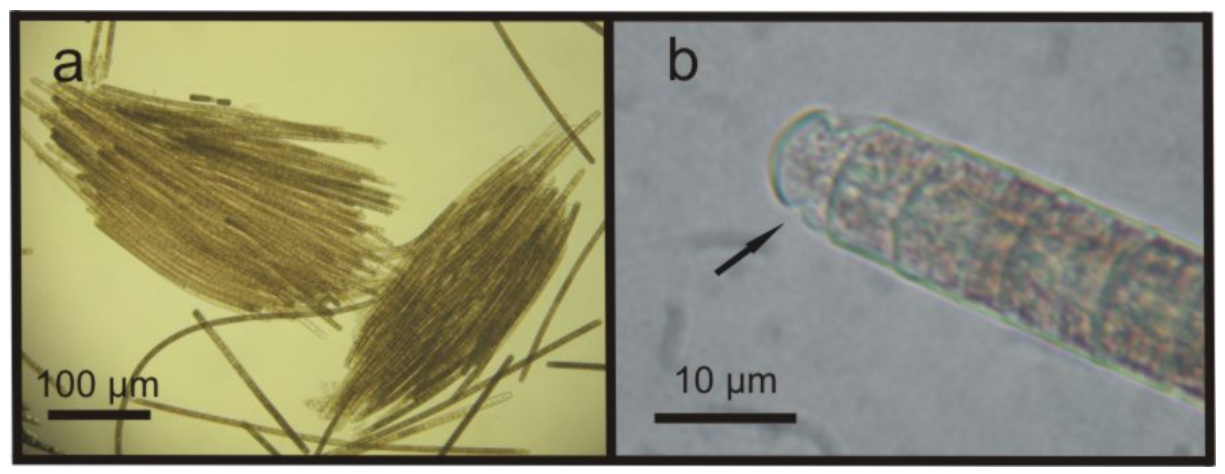

Figure 2. Trichodesmium erythraeum, from sample \#2, showing (a) parallel trichomes and, in detail, (b) showing the caliptra (arrow).

Despite the presence of other organisms - which included diatoms; dinoflagellates such as Prorocentrum rhathymum Loeblich, Shirley \& Schmidt and $P$. minimum (Pavillard) Schiller; tintinids (samples \#1, 3, 4) and copepods (\#2) - their numbers were very low when compared to Trichodesmium (Table 1).

Table 1. List of phytoplankton taxa and their abundances in the four samples analyzed from the Camamu-Almada region

\begin{tabular}{|c|c|c|c|c|}
\hline & \multicolumn{4}{|c|}{ Samples } \\
\hline Phytoplankton taxa & 1 & 2 & 3 & 4 \\
\hline \multicolumn{5}{|l|}{ Cyanophyta } \\
\hline Trichodesmium erythraeum $\left(\times 10^{6}\right)$ & 11.24 & 577.20 & 19.00 & 8.32 \\
\hline \multicolumn{5}{|l|}{ Bacillariophyta } \\
\hline Hemiaulus hauckii & & & & 3700 \\
\hline Mastogloia minuta & & & & 10764 \\
\hline Navicula sp. & & & & 26572 \\
\hline Nitzschia sp. & 333 & 1333 & & 221662 \\
\hline Plagiotropis sp. & & & & 12109 \\
\hline Pseudo-nitzschia sp. & & & & 5382 \\
\hline Thalassionema sp. & 333 & & & 12109 \\
\hline Gomphonema sp. & & & 333 & \\
\hline \multicolumn{5}{|l|}{ Dinophyta } \\
\hline Prorocentrum minimum & & & 3333 & \\
\hline Prorocentrum rhathymum & 333 & 4667 & & \\
\hline Total $\left(\times 10^{6}\right)$ & 11.24 & 577.21 & 19.03 & 8.61 \\
\hline
\end{tabular}


Extracts from all samples showed antimitotic activity observed in sea urchin larvae, even with the more diluted extracts. These results agree with previous studies that found the presence of substances toxic to invertebrates in extracts of $T$. erythaeum from the São Paulo coast (10). Guo and Tester (6) showed that while intact, cells were not toxic to the copepod Acartia tonsa Dana, but their hydrosoluble extracts revealed toxicity, indicating the presence of endotoxins that may be released into the water. Hawser et al. (21) found substances that were only toxic to microcrustaceans in $T$. thiebautii extracts, but not in those from $T$. erythraeum. Despite this finding, it appears that such toxicity does not have a direct impact on mussel aquaculture as in other algae, such as dinoflagellates (22). Rather, these authors found that mussels can be affected by the low nutritional value of these cyanobacteria.

The mouse bioassay did not show acute toxicity. All results from both hydrophilic and lipophilic extracts were negative in the 24-hour test. Some adjustments were necessary to decrease the salinity of extracts by dilution with water, since differences in salinity could mask the results. Although we have found the presence of toxins, as described below, the doses were not sufficient to produce death among tested mice in the manner described in freshwater cyanobacteria toxicity assays (23).

Saxitoxin analogues were measured by HPLC analysis in all extracts, expressed as parts per million (Table 2). At this concentration, the extract did not kill mice under the test conditions. In all nine analogues analyzed, we found only decarbamoyl saxitoxin (dcSTX) and gonyautoxin 3 (GTX 3), which were expressed as a saxitoxin equivalent (19).

Table 2. Toxin concentrations of scum extracts from the Camamu-Almada region

\begin{tabular}{c|c|c}
\hline Sample & $\begin{array}{c}\text { Saxitoxin analogues } \\
\text { STX eq. } \boldsymbol{\mu g} / \mathbf{g}\end{array}$ & $\begin{array}{c}\text { Microcystins } \\
\boldsymbol{\mu g} / \mathbf{g}\end{array}$ \\
\hline$\# 1$ & 1.95 & 89.6 \\
\hline$\# 2$ & 3.40 & 82.7 \\
\hline$\# 3$ & 9.45 & 302.0 \\
\hline$\# 4$ & 2.28 & 9.7 \\
\hline
\end{tabular}

Cylindrospermopsin was not found in the analysis. Table 2 shows the results expressed as Mic-LR. Unlike cilyndrospermopsin, microcystins were encountered in 
all samples by HPLC analysis and were confirmed by ELISA in the sample from 04/07/2007.

The results show that all samples were toxic. The role of toxic substances in Trichodesmium spp. is related mainly to allelopathic functions, which may be very important since these organisms live in environments with low nutrient availability, indicating that competition for this resource may be high (6). Therefore, allopathic substances could be of evolutionary importance. In the same manner, toxic compounds might limit or restrict the grazing on Trichodesmium by microcrustaceans or even by fish. On the other hand, compounds other than the toxins analyzed, such as MIC and STX analogues, can have similar effects since several components can be produced by the same organisms $(6,10,21,24)$.

The presence of microcystin has been reported in samples from a $T$. erythraeum bloom from Canary Island region (25). Sudek et al. (24) reported the presence of a cyclic peptide, called trichamine, with biological activity. Both, saxitoxin and microcystins are produced by freshwater cyanobacteria including Microcystis, Planktothrix, Oscillatoria, Nostoc, Anabaena, Anabaenopsis and Hapalosiphon. These are also found in transitional environments including estuaries, whereas recent studies have shown the presence of microcystin in tiny (picoplankton) Synechococcus spp. in marine environments $(26,27)$. Therefore, it is possible that the microcystin found in the present study is not necessarily related to Trichodesmium erithraeum but rather to co-occurring organisms, or others such as picoplanktonic cyanobacteria. The same is valid for saxitoxin. In extracts from Australian Trichodesmium, Negri et al. (22) did not observe the presence of saxitoxin. But these toxins were observed in a Trichodesmium erythraeum bloom off the Rio Grande do Sul coast, Brazil, in March 2004 (28). In this event, SXT, GTX1, GTX3 and GTX4 were identified and toxicity was confirmed by the mouse bioassay. In marine environments, several dinoflagellates produce these toxins, as do some bacteria (29). In our case, further assays will be necessary to investigate the true source of the toxins. Samples of T. erythraeum from off the Santa Catarina coast did not present either mice toxicity or microcystin (4). It is possible, therefore, that other co-occurring organisms may also produce the toxic compounds found in these tests. Prorocentrum rhathymun and $P$. minimum, for example, are dinoflagellates that can provoke toxic effects (30). 
In humans, both saxitoxin and microcystin toxins can become problematic. Drinking water containing microcystins and other cyanotoxins causes shortages in water supplies and can lead to several health problems (23). In Brazil, the presence of such compounds in potable and recreational water is regulated by specific laws (31). However, microcystin does not cause harm through direct contact. Thus, although the toxins are present in these microorganisms, we do not consider these blooms a health problem. There is no report of Trichodesmium toxin magnification through trophic chains by mussels, filter feeders or fishes, in contrast with dinoflagellates (22). Blooms reaching mussel culture areas in Santa Catarina have not caused any observable damage.

Despite their broad geographic occurrence along the Brazilian coast, up to now, the only reported harmful effect on humans, published by Satô et al. in 1963 (5), was human illness along the coast of Pernambuco (more precisely, at Tamandaré, a city by the sea). Since that episode, no other harmful event has been registered in Brazil. For example, in 2004, a large portion of Cassino beach, in Rio Grande do Sul, was covered by a $T$. erythraem bloom but no injurious effects were registered (28). The same was true for Santa Catarina, Paraná and Bahia states. The etiology of the Tamandaré event needs to be investigated more thoroughly. In the study that reports the illness associated with the incident, no attempts were made to elucidate the toxin origin or to perform toxicity tests. Since then no other paper has been published relating human illness to the presence of Trichodesmium spp. blooms.

In general, no direct actions have been taken following the discovery of Trichodesmium spp. blooms in any place. In spite of this, CETESB, the environmental agency of São Paulo state, usually advises people not to use beaches during an algal bloom. This may be a valid precautionary procedure since it is known that some cyanobacteria can cause dermatitis, and that dinoflagellates may produce toxins carried by aerosols. At this point, we cannot definitively associate harmful effects with Trichodesmium spp. blooms.

\section{REFERENCES}

1. Janson S, Siddiqui PIA, Walsby AE, Romans KM, Carpenter EI, Bergmen B. Cytomorphological characterization of the planktonic diazotrophic cyanobacteria Trichodesmium spp. from the Indian Ocean and Caribean and Sargasso Seas. J Phycol. 1995;31(3):463-77. 
2. Desikachary TV. Cyanophyta. New Delhi: Indian Council Agricultural Research; 1959. 686 p.

3. Capone DG, Zehr JP, Paerl HW, Bergman B, Carpenter EJ. Trichodesmium, a globally significant marine cyanobacterium. Science. 1997;276(5316):1221-9.

4. Rörig L, Yunes JS, Kuroshima K, Schettini CAF, Pezzuto PR, Proença LAO. Studies on the ecology and toxicity of Trichodesmium spp. blooms in Southern Brazilian coastal waters. $8^{\text {th }}$ International Conference on Harmful Algae; 1998. Espanha: Harmful Algae; 1998. 22-5 p.

5. Satô S., Paranaguá MN., Eskinazi E. On the mechanism of red TIDE of Trichodesmium in Recife north eastern Brazil, with some considerations of the relation to the human disease Tamandaré Fever. Trabhs Inst Oceanogr (Univ Recife). 1966;5(6):7-49.

6. Guo C, Tester PA. Toxic effect of the bloom-forming Trichodesmium sp. (Cyanophyta) to the copepod Acartia tonsa. Nat Toxins. 1994;2(4):222-7.

7. Brandini FP. Composição e distribuição do fitoplâncton na região sudeste do Brasil e suas relações com as massas de água (Operação sudeste julho/agosto 1982). Ciência e Cultura. 1988;40(4):334-41.

8. Siqueira A, Kolm HE, Brandini FP. Offshore distribution patterns of the cyanobacterium Trichodesmium erythraeum ehrenberg and associated phyto- and bacterioplankton in the southern Atlantic Coast (Paraná, Brazil). Braz Arch Bioll Technol. 2006;49(2):323-37.

9. CETESB (Companhia de Tecnologia e Saneamento Ambiental do Estados de São Paulo). Florações de microalgas no ambiente marinho [Internet]. São Paulo: CETESB; $2007 . \quad$ Available from: <http://www.cetesb.sp.gov.br/Agua/praias/algas.asp>.

10. Fonseca ML, Silva MA, Freitas JC. Ensaios preliminares da toxicidade de extratos de uma amostra de Trichodesmium erythraeum do Canal de São Sebastião, SP. XVII Simpósio de Biologia Marinha - Cebimar/USP; 2002. São Sebastião, SP: Caderno de Resumos e Palestras do XVII Simpósio de Biologia Marinha Cebimar/USP; 2002.

11. Gianesella-Galvão SMF, Costa MPF, Kurtner MB. Bloom of Oscillatoria (Trichodesmium) Erythraea (Ehr.) kutz in coastal waters of the Southweast Atlantic. Publ Esp Inst Oceonograf. 1995;11:133-40. 
12. Utermohl H. Zur vervollkommnung der quantitativen phytoplankton methodik. Mitt int Verein theor angew Limnol. 1958;9(1):1-38.

13. Cortés-Altamirano R, Sierra-Beltrán AP. Morphology and taxonomy of Prorocentrum mexicanum and reinstatement of Prorocentrum rhathymum (Dinophyceae). J Phycol. 2003;39(1):221-5.

14. Cupp ED. Marine plankton diatoms of the west coast of North America. Bull Scripps Inst Oceanograf. 1943;5(1):1-238.

15. Steidinger KA, Tangen K. Dinoflagellates. In: Tomas CR, editor. Identifying marine diatoms and dinoflagellates. San Diego: Academic Press, Inc.; 1996. p. 387584.

16. CETESB (Companhia de Tecnologia e Saneamento Ambiental do Estado de São Paulo). Água do mar - teste de toxicidade crônica de curta duração com Lytechinus variegatus Lamarck, 1816 (Echinodermata: Echinoidea). São Paulo: CETESB; 2002. $22 \mathrm{p}$.

17. Harada K, Kondo F, Lawton L. Laboratory analysis of cyanotoxins. In: Chorus I., Barthram J, editors. Toxic cyanobacteria in water: a guide to their public health consequences, monitoring and management. New York: World Health Organization, E\&F.N. Spon; 1999. 368-405 p.

18. Lawton L, Beattie KA, Hawser SP, Campbell DL, Codd GA. Evaluation of assay methods for the determination of cyanobacterial hepatotoxicity. In: Codd GA, Jefferies TM, Keevil CW, Potter E, editors. Detection methods for cyanobacterial toxins. Cambridge: The Royal Society of Chemistry; 1994. 111-6 p.

19. Oshima Y. Postcolumn derivatization liquid chromatographic method for paralytic shellfish toxins. J AOAC Int. 1995;78:528-32

20. Li R, Carmichael WW, Brittain S, Eaglesham GK, Shaw GR, Liu Y, Watanabe MM. First report of the cyanotoxins cylindrospermopsin and deoxicylindrospermopsin from Raphidiopsis curvata (Cyanobacteria). J Phycol. 2002;37(6):1121-6.

21. Hawser SP, O'neil JM, Roman MR, Codd GA. Toxicity of blooms of the cyanobacterium Trichodesmium to zooplankton. J Appl Phycol. 1992;4(1):79-86.

22. Negri AP, Bunter $O$, Jones B, Llewllyn L. Effects of the bloom-forming alga Trichodesmium erythraeum on the pearl oyster Pinctada maxima. Aquaculture. 2004; 232(1-4):91-102. 
23. Chorus I, Bartram J. Toxic cyanobacteria in water: a guide to their public health consequences, monitoring and management. New York: World Health Organization, E\&F.N. Spon; 1999. 416 p.

24. Sudek S, Haygood MG, Youssef DT, Schmidt EW. Structure of trichamide, a cyclic peptide from the bloom-forming cyanobacterium Trichodesmium erythraeum, predicted from the genome sequence Appl Environ Microbiol. 2006;72(6):4382-7.

25. Ramos AG, Martel A, Codd GA, Soler E, Coca J, Redondo A, Morrison LF, Metcalf JS, Ojeda A, Suárez S, Petit M. Bloom of the marine diazotrophic cyanobacterium Trichodesmium erythraeum in the northwest African upwelling. Marine Ecology, 2005;301:303-5.

26. Carmichael WW, Li R. Cyanobacteria toxins in the Salton Sea. Saline Systems. 2006;2:5.

27. Domingos P, Rubim TK, Molica RJR, Azevedo SMFO, Carmichael WW. First report of microcystin production by picoplanktonic cyanobacteria isolated from a northeast Brazilian drinking water supply. Environ Toxicol. 1999;14(1):31-5.

28. Silva LM. Ocorrência de cianobactérias no estuário e costa adjacente à Lagoa dos Patos, Rio Grande, RS: avaliação preliminar dos riscos a balneabilidade [master's thesis]. [Rio Grande do Sul (RS)]: Universidade Federal do Rio Grande, FURG; 2005. 129 p.

29. Kodama M, Ogata T, Sato S, Sakamoto S. Possible association of marine bacteria with paralytic shellfish toxicity of bivalves. Mar Ecol Prog Ser. 1990;61:2036.

30. Moestrup $\varnothing$, editor. IOC taxonomic reference list of toxic plankton algae. Intergovernmental Oceanographic Commission of UNESCO [internet]. Available from: <http://www.bi.ku.dk/ioc/introduction.asp>.

31. Brasil. Ministério da Saúde. Portaria n. 518, de 25 de março de 2004. Brasília: D.O.U. - Diário Oficial da União; 2004. 